\title{
Dietary protein intake and 3-methylhistidine excretion in the rat
}

\author{
BY L. C. WARD* AND P. J. BUTTERY \\ Department of Applied Biochemistry and Nutrition, University of Nottingham, \\ School of Agriculture, Sutton Bonington, Loughborough, LEI2 $5 R D$
}

(Received 24 November 1978 - Accepted 27 June 1980)

1. Rats were fed for $14 \mathrm{~d}$ on diets containing 50,150 or $250 \mathrm{~g} / \mathrm{kg}$ casein as the protein source. The daily excretion of $\mathrm{N}^{2}$-methylhistidine (His $(\tau \mathrm{Me})$ ), a non-re-utilized amino acid, was determined.

2. His $(\tau \mathrm{Me})$ excretion/100 g body-weight appeared to be unaffected by increasing the concentration of dietary protein from 150 to $250 \mathrm{~g} / \mathrm{kg}$. Assuming no change in the proportion of muscle in the animals these results are indicative of no change in myofibrillar protein catabolic rate. The excretion rate/I00 $\mathrm{g}$ body-weight of the animal given $50 \mathrm{~g} / \mathrm{kg}$ casein was lower than the other two treatments, especially towards the end of the I4 $\mathrm{d}$ treatment period. Thus at this time the myofibrillar protein catabolic rate was lower than in the animals fed on the higher protein diet.

3. In the animals fed on the high protein diet there was a tendency for this ( $7 \mathrm{Me})$ excretion rate/100 $\mathrm{g}$ body-weight to increase with age.

4. Nitrogen balance and creatinine excretion results are also presented.

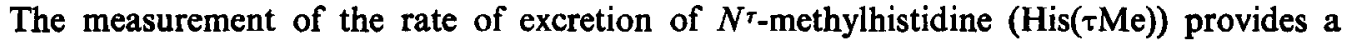
method for the continuous monitoring of the breakdown of myofibrillar proteins in muscle. Whilst the caution with which results obtained using this technique should be interpreted cannot be over emphasized, the technique would appear to be valid (for review see Ward \& Buttery, 1978). Using this technique Young et al. (1973) demonstrated a decrease in myofibrillar protein breakdown in man during starvation for $20 \mathrm{~d}$ while Rao \& Nagabhushan (1973) have demonstrated a similar reduction in catabolic rate in man during protein-energy malnutrition. Haverberg et al. (1975) have also reported similar results in protein-energy malnourished rats. Nishizawa et al. (1977) observed an increase in the breakdown of myofibrillar proteins following feeding high-protein diets to rats.

Since in these previously published studies only relative extremes of protein depletion and supplementation were investigated it seemed desirable to study the changes in urinary His ( $\tau \mathrm{Me}$ ) excretion that occur when animals are fed on diets containing a comparatively moderate excess or deficiency of protein and to relate these changes to the over-all nitrogen status of the animal. Such a study has particular relevance to comparable studies in large farm animals, particularly cattle where the His $(\tau \mathrm{Me})$ technique would appear to be valid (Harris \& Milne, 1978), as such animals are unlikely to experience such extreme variation in the composition of the diet as used in the previously reported studies with the rat referred to previously.

In the present report the results of the effects of diets containing 50, I 50 or $250 \mathrm{~g}$ casein $/ \mathrm{kg}$ on the His( $(\mathrm{Me})$ excretion and $\mathrm{N}$ status of rats are reported.

* Present address: Department of Biochemistry, University of Queensland, Brisbane, Queensland, Australia 4067.

$0007-1145 / 80 / 3255-2706$ \$01 .00 @ 1980 The Nutrition Society 
Table $\mathrm{r}$. Composition $(\mathrm{g} / \mathrm{kg})$ of laboratory rodent diet and experimental diets with different casein concentrations

Laboratory rodent diet
Ground wheat
Ground oats
Dried skimmed milk
Dried yeast
White fish meal
Vitamin supplement
Mineral mix
Fat (tallow)
Sodium chloride
Cod liver oil
Bentonite

Experimental diet...

\section{Casein}

Dextrin starch

Maize starch

Arachis oil

Mineral mix*

Vitamin mix*

DL-methionine

Vitamins (A, D, E; in oil)*

Gross energy $(\mathrm{MJ} / \mathrm{kg})$

Protein (nitrogen $\times 6 \cdot 25$ )

Low-protein
50
300
537
50
50
11
1.0
1.0
15.46
47.5

450
268
25
25
150
$4 \cdot 5$
$9 \cdot 7$
50
$4 \cdot 5$
$4 \cdot 5$
$8 \cdot 8$

$\begin{array}{cc}\text { Adequate-protein } & \text { High-protein } \\ 150 & 250 \\ 300 & 300 \\ 437 & 337 \\ 50 & 50 \\ 50 & 50 \\ 11 & 11 \\ 1 \cdot 0 & 1 \cdot 0 \\ 1 \cdot 0 & 1 \cdot 0 \\ 16.59 & 17 \cdot 21 \\ 137.5 & 218 \cdot 1\end{array}$

* For detailed composition of mineral mix, vitamin mix and fat soluble vitamins see Payne \& Stewart (1972).

\section{METHODS}

Twelve male rats (Wistar strain, specific pathogen free) were weight-sorted into three groups. The rats were placed at random in stainless-steel metabolism cages. They were fed on a standard laboratory diet (Table $\mathrm{I}$ ) ad lib. and after $7 \mathrm{~d}$ each group of four rats was fed on one of the three experimental diets shown in Table I. Each rat was allowed free access to the experimental diet and to water. Urine and faeces were collected separately, the urine being collected in approximately $0.5 \mathrm{ml} 6 \mathrm{M}$-hydrochloric acid. At the same time each day the rats were weighed, the food intake for each rat recorded and the urine and faeces for each group of rats collected and pooled. The samples were stored at $-15^{\circ}$ before analysis.

\section{Analytical procedures}

Urine samples were desalted before amino acid analysis by the method of Armstrong (1966). The desalted urine samples were hydrolysed under reflux with excess $6 \mathrm{M}-\mathrm{HCl}$ at $1 \mathrm{IO}^{\circ}$ for $22 \mathrm{~h}$ to convert any $\mathrm{N}$-acetyl methylhistidine to methylhistidine (Young et al. 1972). The His $(\tau \mathrm{Me})$ concentration in the pooled urine samples prepared as above was determined according to the method of Atkin \& Ferdinand (1970) using either a Locarte (London) or an Evans Electroselenium model 294 (Halstead, Essex) amino acid analyser. The concentration of His $(\tau \mathrm{Me})$ in tissue protein was determined from acid hydrolysates prepared from trichloroacetic acid-precipitated protein. The recovery of $\mathrm{His}(\tau \mathrm{Me})$ added to samples prepared by this procedure was $95-102 \% . \mathrm{N}$ in food and in the daily pooled urine and pooled faecal samples was determined by the Kjeldahl method in accordance with the recommendations of the Association of Official Analytical Chemists (1975). The concentration of creatinine in the pooled urine samples was determined according to the method of Owen et al. (1954). 


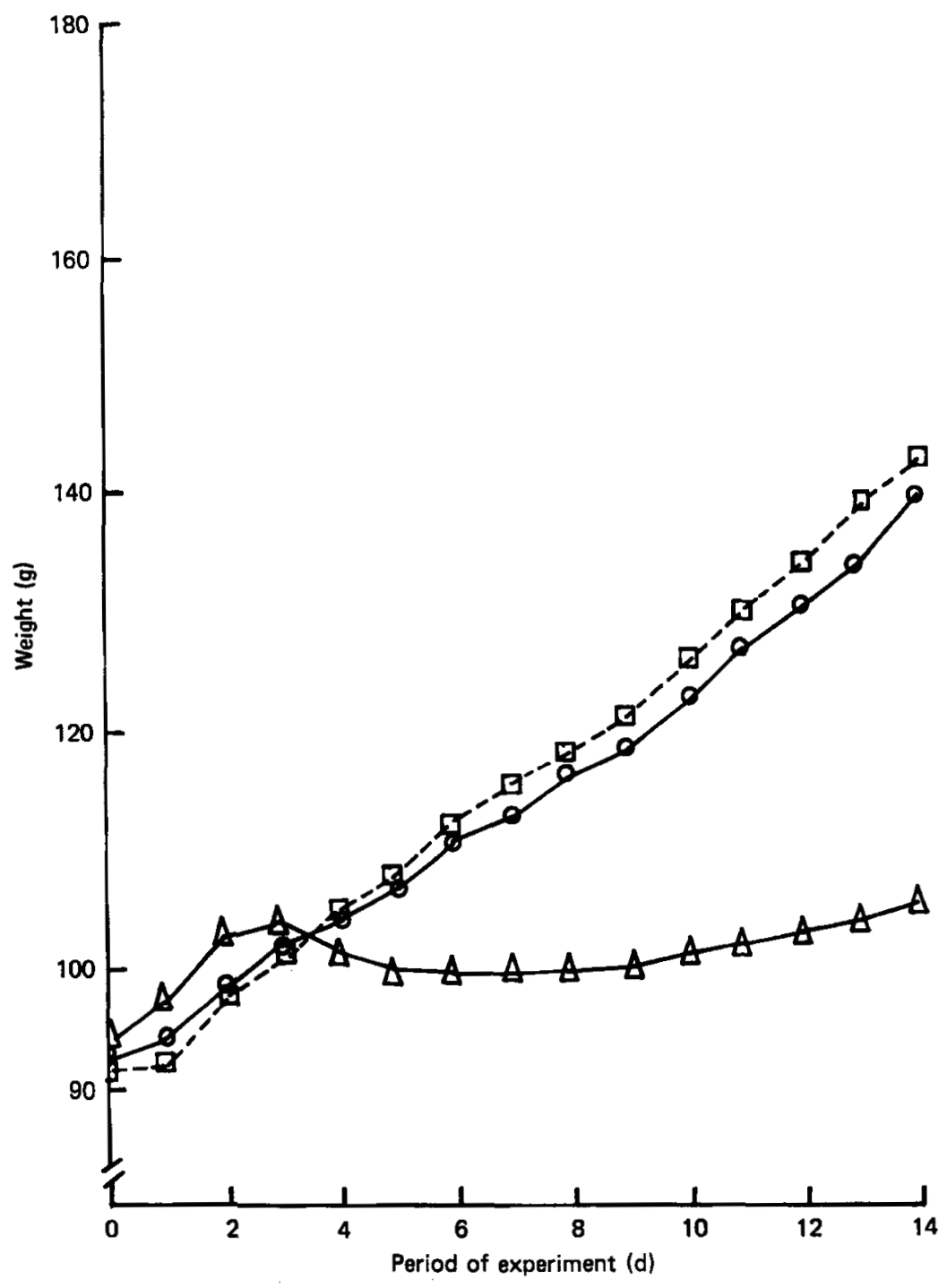

Fig. 1. Cumulative weight gain ( $\mathrm{g}$ ) of rats fed on diets containing three different concentrations of protein. Three groups of rats, four/group, were fed on diets containing $50(\Delta-\Delta), 150$ $(\mathrm{O}-\mathrm{O})$ or $250(\square--\square) \mathrm{g}$ casein/kg. A standard laboratory diet (Table I) was fed before feeding the experimental diets. The cumulative weight gain of the rats was determined daily.

\section{Statistical analysis}

Where applicable, the resuits are expressed as mean values with their standard errors. The significance of difference between the means was estimated using Student's ' $t$ ' test (Snedecor \& Cochran, 1967). 


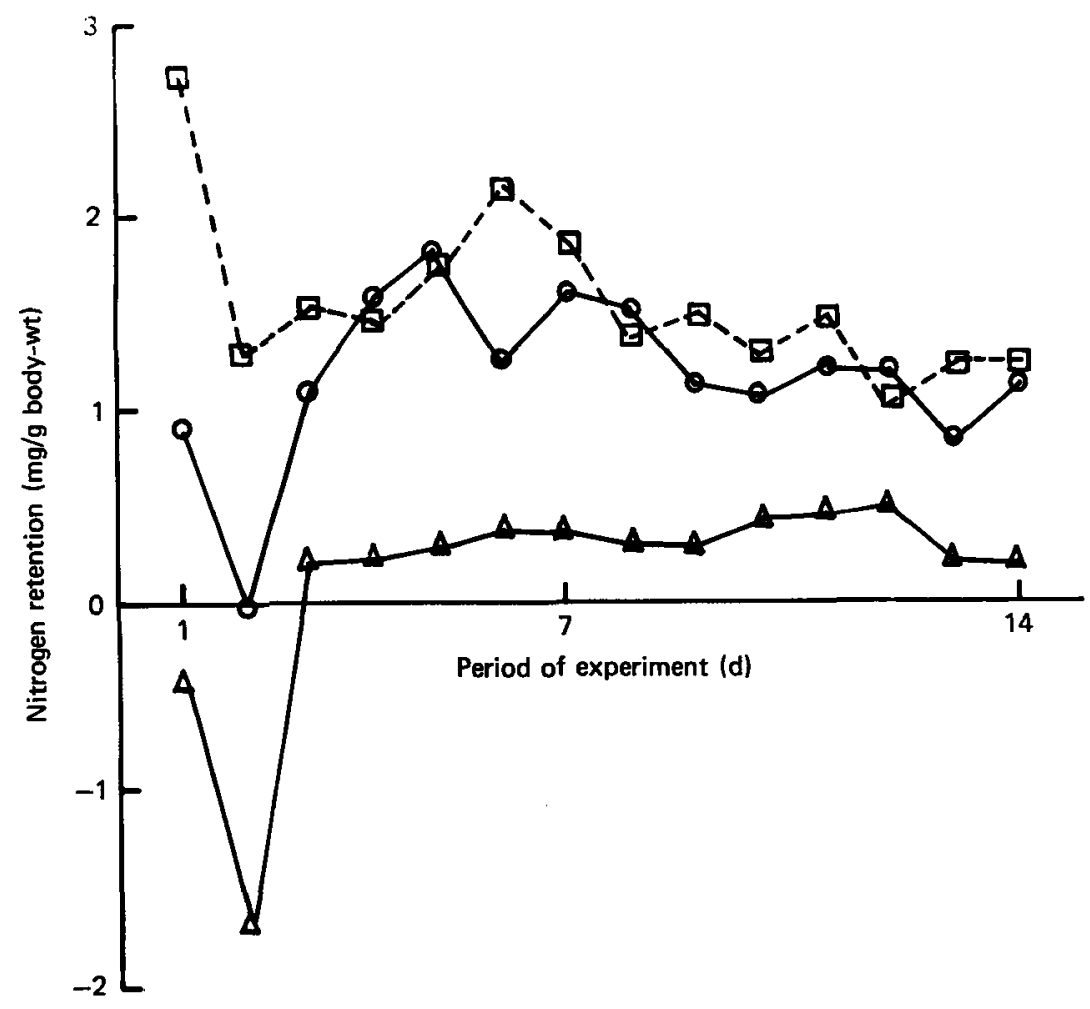

Fig. 2. Nitrogen retention (mg/g body-weight) by rats fed on diets containing three different concentrations of protein. Three groups of rats, four/group, were fed on diets containing 50 $(\Delta-\Delta), 150(\mathrm{O}-\mathrm{O})$ or $250(\square--\square) \mathrm{g}$ casein/kg. A standard laboratory diet (Table $\mathrm{I})$ was fed before feeding the experimental diets. $N$ retention was calculated as described on p. 385 . Values were determined from pooled samples for each group.

\section{RESULTS}

Changes in body-weight and food intake during feeding of the experimental diets

The rats fed on the diets containing 150 and $250 \mathrm{~g}$ casein $/ \mathrm{kg}$ continued to gain weight during the experimental period, 3.4 and $3.7 \mathrm{~g} / \mathrm{d}$ respectively (Fig. I).

The rats receiving the diet containing $50 \mathrm{~g}$ casein $/ \mathrm{kg}$ after $3 \mathrm{~d}$ lost weight and only started to regain weight $(0.9 \mathrm{~g} / \mathrm{d})$ after receiving the experimental diet for $7 \mathrm{~d}$. The differences in the mean body-weights between groups of rats before feeding the experimental diets was not significant. Rats fed on the diet containing $50 \mathrm{~g}$ casein $/ \mathrm{kg}$ were generally lighter than those fed on diets containing 150 or $250 \mathrm{~g}$ casein $/ \mathrm{kg}$ and this difference was significant $(P<0.05)$ on days 8 and 6 respectively. These differences were maintained $(P<0.0 \mathrm{I})$ at the end of the experiment, whereas the difference between the rats fed on the two higher-protein diets was not significant $(P>0.05)$.

There was no statistically significant difference over the $14 \mathrm{~d}$ feeding period in the mean daily food intake between the rats receiving the diets containing 150 or $250 \mathrm{~g}$ casein $/ \mathrm{kg}$ ( 10.3 and $11.4 \mathrm{~g} / \mathrm{d}$ respectively). The differences in daily food intake between rats receiving the diet containing $50 \mathrm{~g}$ casein $/ \mathrm{kg}(9.3 \mathrm{~g} / \mathrm{d})$ and either those receiving the diet containing $150 \mathrm{~g}$ casein $/ \mathrm{kg}$ or those receiving the diet containing $250 \mathrm{~g}$ casein $/ \mathrm{kg}$ were statistically significant $(P<0.05)$ on days $11,12,13$ and 14 . 


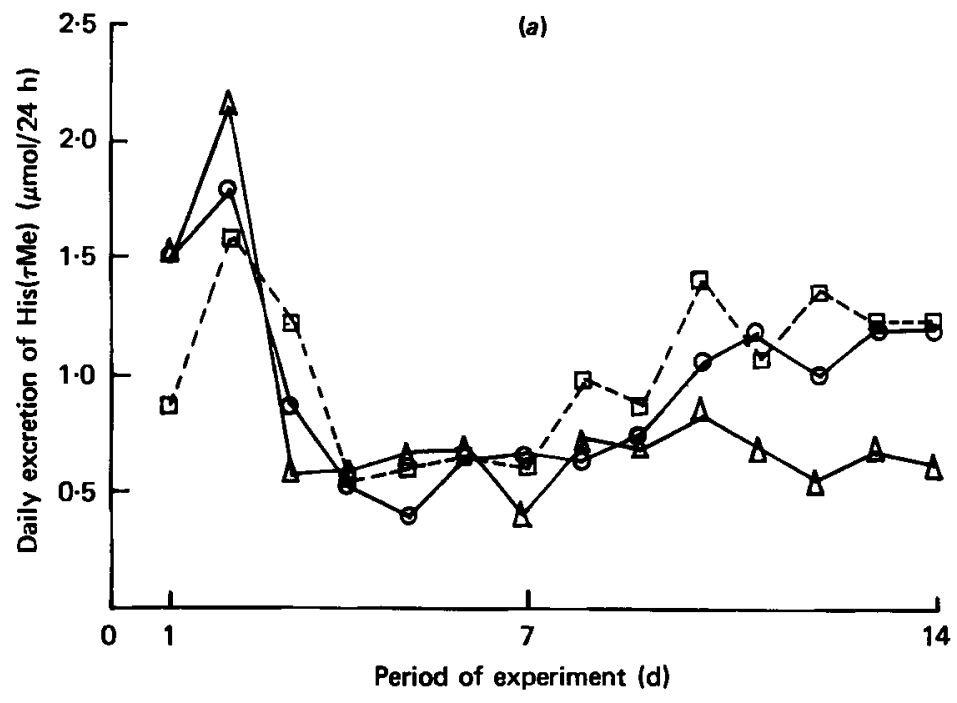

(b)

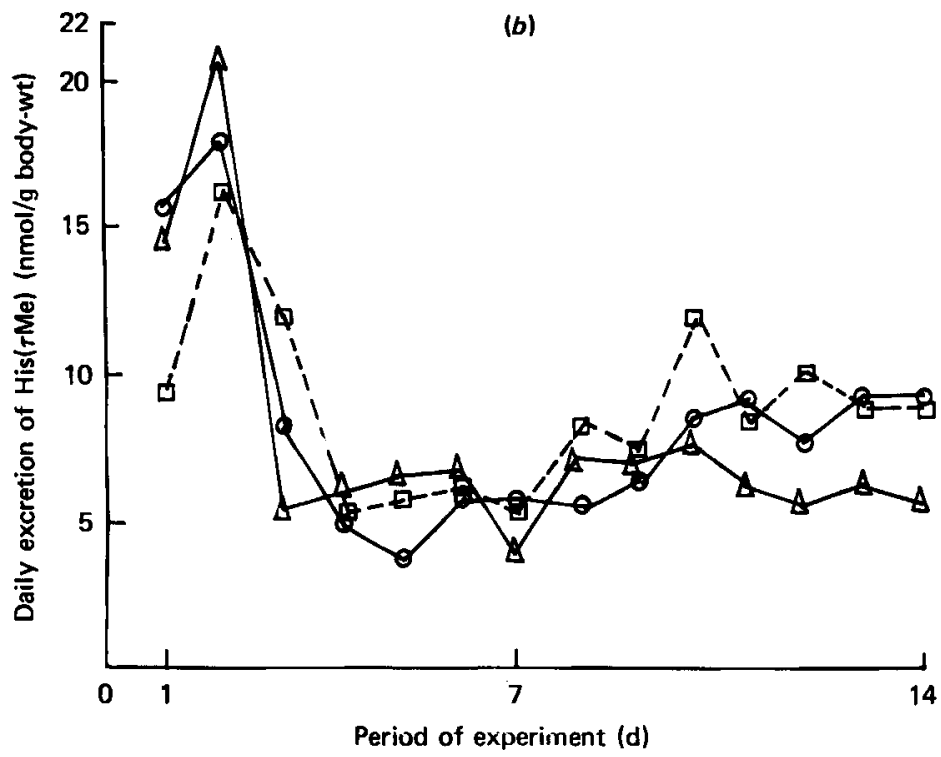

Fig. 3. Daily excretion ( $\mathrm{nmol}(a)$, $\mathrm{nmol} / \mathrm{g}$ body-weight $(b)$ ) of $N^{\tau}$-methylhistidine (His ( $\tau \mathrm{Me}$ )) by rats fed on diets containing three different concentrations of protein. Three groups of rats, four/group, were fed on diets containing $50(\Delta-\Delta)$, $150(\mathrm{O}-\mathrm{O})$ or $250(\square--\square) \mathrm{g}$ casein/kg. A standard laboratory diet (Table I) was fed before feeding the experimental diets. Urinary His $(\tau \mathrm{Me})$ was determined as described on p. 382. Values were determined from pooled samples for each group.

\section{$N$ retention during feeding of the experimental diets}

$\mathbf{N}$ retention values for the three groups of rats are shown in Fig. 2. $\mathbf{N}$ retention has been expressed as $\mathrm{mg} N$ retained/g body-weight. $\mathrm{N}$ retention was calculated as the difference between $\mathrm{N}$ intake (food intake $(\mathrm{g}) \times \mathbf{N}$ concentration in the $\operatorname{diet}(\mathrm{mg} / \mathrm{g})$ ) and total $\mathrm{N}$ loss in 
the faeces and urine. All calculations were made using the mean values for each group of rats. Except for the first $3 \mathrm{~d}$ all three groups of rats maintained a positive $\mathrm{N}$ retention. $\mathrm{N}$ retention of the rats receiving the diets containing 150 or $250 \mathrm{~g}$ casein $/ \mathrm{kg}$ was similar and fell slightly during the experimental period. $\mathrm{N}$ retention of the rats receiving the diet containing $50 \mathrm{~g}$ casein $/ \mathrm{kg}$ was constant during the experimental period and was $23 \%$ of that of rats receiving the higher-protein diets.

The sharp depression in $\mathrm{N}$ retention after the start of the feeding trial may be a result of the adaptation to the change in diet. There was evidence of a check in the rate of weight gain (Fig. I). The slight positive $\mathrm{N}$ balance without any apparent concomitant growth shown by the rats fed on the $50 \mathrm{~g}$ casein $/ \mathrm{kg}$ diet probably reflects the inherent errors in the $\mathrm{N}$ balance technique but the possibility of a progressive change in body composition cannot be dismissed. Such a systematic change throughout the last ro $\mathrm{d}$ of the feeding trial would, however, appear unlikely.

\section{$N^{\top}$-methylhistidine and creatinine excretion during feeding of the experimental diets}

Daily excretion of His $(\tau \mathrm{Me})$ by the three groups of rats is shown in Fig. 3. The peak in excretion of $\mathrm{His}(\tau \mathrm{Me})$ may reflect some marked change in myofibrillar protein breakdown following adaptation to the experimental diets. It is relevant to note that on this day there was also a marked drop in $\mathrm{N}$ retention. This increase may also in part reflect excretion of $\mathrm{His}(\mathrm{re})$ originating from the diet the rats had been receiving before being fed on the experimental diets. His( $\tau \mathrm{Me}$ ) has been found in fish muscle (Poulter et al. 1977) and is quantitatively excreted (Young et al. 1972). Fish meal was included in the standard laboratory diet and has been shown to contain $\mathrm{His}(\tau \mathrm{Me})$ at a concentration of $0.2 \mu \mathrm{mol} / \mathrm{g}$ dry weight (Ward, 1976). Since no His( $\tau \mathrm{Me})$ was present in the experimental diets, excretion of His( $\tau \mathrm{Me})$ during days $4^{-I} 4$ of the trial was considered to reflect endogenous His( $\left.\tau \mathrm{Me}\right)$ excretion i.e. from muscle protein breakdown. The validity of this assumption has been discussed elsewhere (Ward \& Buttery, 1978). Daily His( $\tau \mathrm{Me})$ excretion was similar for the rats receiving the diets containing 150 or $250 \mathrm{~g}$ casein $/ \mathrm{kg}$ and increased during the experimental period. His( $\tau \mathrm{Me}$ ) excretion increased by approximately $130 \%$ between day 4 and day $\mathrm{I} 4$ (Fig. $3 a$ ). This increased excretion of His( $\tau \mathrm{Me})$ during the experimental period did not simply reflect the increased body-weight of the rats since His( $\tau \mathrm{Me})$ excretion/g body-weight also increased ( $49 \%$ greater on day I 4 than on day 4 ) (Fig. $3 b$ ). The rats fed on the diet containing $50 \mathrm{~g}$ casein $/ \mathrm{kg}$ excreted constant amounts of His $(\tau \mathrm{Me}$ ) each $24 \mathrm{~h}$ (Fig. $3 a$ ) and excretion of $\mathrm{His}(\tau \mathrm{Me}) / \mathrm{g}$ body-weight also remained constant (Fig. $3 b$ ) at least during days $4-14$ of the trial.

It is instructive to consider the ratio of $\mathrm{His}(\tau \mathrm{Me})$ to that of creatinine in the urine as an indicator of the rate of muscle protein degradation relative to muscle mass (Fig. 4). All groups of rats exhibited a decline in $\mathrm{His}(\tau \mathrm{Me})$ excretion per unit of creatinine between days 2 and 4 of the trial. Thereafter the excretion of $\mathrm{His}(\tau \mathrm{Me})$ relative to creatinine was constant in those rats receiving the low-protein diets indicating that protein depletion may be associated with parallel changes in muscle mass and His( $\tau \mathrm{Me})$ excretion. In contrast whilst there was a large daily variation in this ratio there was evidence of an increase in His( $\tau \mathrm{Me})$ excretion per unit of creatinine by rats fed on the diets containing either 150 or $250 \mathrm{~g}$ casein $/ \mathrm{kg}$ (Fig. 4). Thus, in these groups of rats, this His( $(\mathrm{Me})$ excretion appears to alter independently of creatinine excretion and thus presumably of muscle mass.

The concentration of $\mathrm{His}(\tau \mathrm{Me})$ in muscle protein measured at the end of the trial was not significantly altered $(P>0.05)$ by the concentration of protein in the diet $(0.74 \pm 0.02(4)$, $0.80 \pm 0.30(4)$ and $0.77 \pm 0.03(4) \mu \mathrm{mol} / \mathrm{g}$ muscle wet weight for rats fed on diets containing 50, I 50 and $250 \mathrm{~g}$ casein $/ \mathrm{kg}$ respectively). 


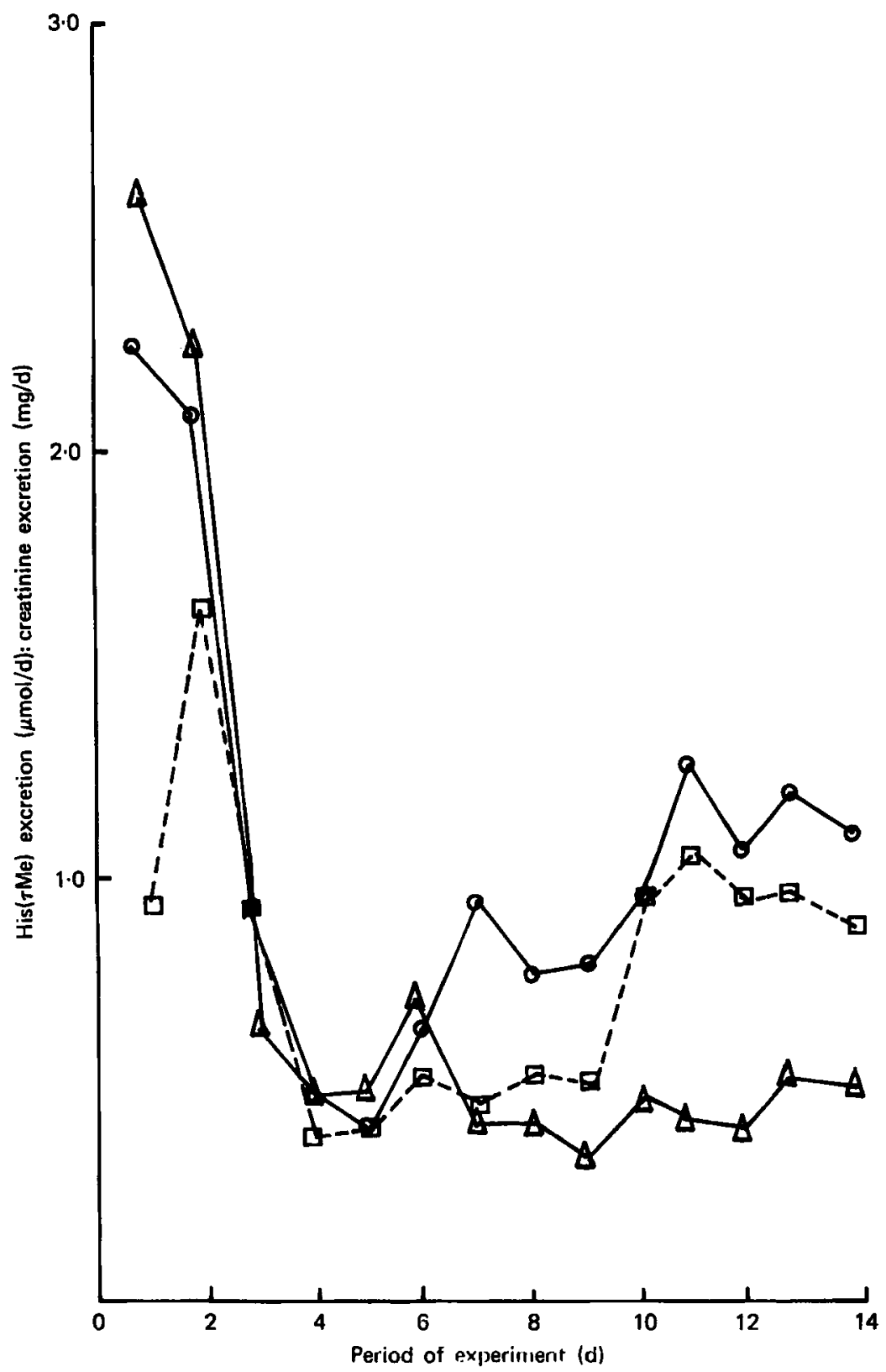

Fig. 4. Daily excretion of $N^{\tau}$-methylhistine/unit creatinine by rats fed on diets containing three different concentrations of protein. Three groups of rats, four/group, were fed on diets containing $50(\Delta-\Delta), 150(\mathrm{O}-\mathrm{O})$ or $250(\square--\square) \mathrm{g}$ casein/kg. A standard laboratory diet (Table $\mathrm{I})$ was fed prior to feeding the experimental diets. Urinary His(rMe) and creatinine were determined as described in the text. Values were determined from pooled samples for each group. 
The rate of His( $\tau \mathrm{Me})$ excretion during protein deficiency has been determined by Haverberg et al. (1975). They observed a progressive decrease in urinary output of His( $(\mathrm{Me})$ which greatly exceeded the decline in body-weight. This observation implies metabolic adaptation in order to conserve muscle protein from loss through breakdown. In the present study His $(\tau \mathrm{Me})$ excretion was initially unaffected by protein deficiency and a constant excretion per unit body-weight was observed (Fig. $3 b$ ). The output of His $(\tau \mathrm{Me}$ ) from the rats on the $50 \mathrm{~g} / \mathrm{kg}$ treatment however became lower than that of the rats on the other two treatments as the trial progressed. Thus at the end of the trial period the myofibrillar catabolic rate was lower than in the rats fed on the higher dietary protein content. This pattern of change is contrary to the observations of Haverberg et al. (1975) noted previously. However, the results are not strictly comparable, since Haverberg et al. (1975) used a very severe protein depletion ( $5 \mathrm{~g}$ lactalbumin/ $\mathrm{kg}$ diet), which caused a significant progressive decrease in bodyweight compared with the less severe treatment ( $50 \mathrm{~g}$ casein $/ \mathrm{kg}$ ) used in the present study which caused no significant change in weight (Fig. I).

The assumption that a constant rate of $\mathrm{His}(\tau \mathrm{Me})$ excretion during low protein feeding is indicative of a constant catabolic rate is valid only if ingestion of the diet does not affect His $(\tau \mathrm{Me})$ excretion per se and that the concentration of $\mathrm{His}(\tau \mathrm{Me})$ in the myofibrillar protein pool is unchanged (Ward \& Buttery, 1978). The results presented in this study indicate that the concentration of $\mathrm{His}(\tau \mathrm{Me})$ in the myofibrillar pool was not altered markedly by the protein concentration of diet. Haverberg et al. (1975), in their study, showed that the His( $\tau \mathrm{Me})$ concentration in actin was $5 \%$ lower in protein-deficient rats compared with wellfed controls. This difference was significant but insufficient to account for the low urinary output of $\mathrm{His}(\tau \mathrm{Me})$ by the protein-deficient rats.

In the present study, the feeding of a high-protein $(250 \mathrm{~g}$ casein $/ \mathrm{kg}$ ) diet did not appear to alter His $(\tau \mathrm{Me})$ output, either absolutely or per unit body-weight, when compared with an adequate ( $150 \mathrm{~g}$ casein $/ \mathrm{kg}$ ) diet. This is in contrast to the results of Nishizawa et al. (1977) who observed an increase in $\mathrm{His}(\tau \mathrm{Me})$ excretion concomitant with an increase in dietary

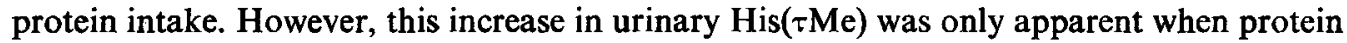
concentration in the diet was greater than $400 \mathrm{~g} / \mathrm{kg}$. The creatinine:His(-Me) value also showed a tendency to increase with increasing protein intake. It would appear, therefore, that a moderate increase in protein intake does not change markedly $\mathrm{His}(\tau \mathrm{Me})$ excretion.

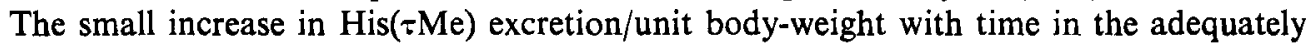
fed rats ( 150 and $250 \mathrm{~g}$ casein $/ \mathrm{kg}$ diets) is difficult to explain since other evidence would indicate that the rate of muscle protein breakdown decreases with age (see for example Millward et al. 1975, who estimated the breakdown of the mixed proteins of rat muscle following determination of fractional synthetic and growth rates). Haverberg et al. (1975), observed in their control rats (i.e. those fed $180 \mathrm{~g} / \mathrm{kg}$ lactalbumin) a general decline in the rate of $\mathrm{His}(\tau \mathrm{Me})$ histidine excretion/unit body-weight as this experiment progressed, especially during the latter part of their $28 \mathrm{~d}$ feeding trial. It is, however, interesting to note that during the first few days of their trial they noted a marked drop in His( $\tau \mathrm{Me})$ excretion, presumably an adaption from the standard laboratory diet to the experimental diet. This was observed during the present study also. This marked drop in His $(\tau \mathrm{Me})$ excretion was followed by a small rise in the excretion rate for approximately io d. Perhaps both in the study of Haverberg et al. (1975) and in the present work this observed rise in His(tMe) excretion was another consequence of the adaption to a different type of diet. Whether the surge of His( $\tau \mathrm{Me})$ seen initially on changing the diet comes from the myofibrills of the skeletal muscle or from another source, either protein bound or free cannot be determined from the results presented here. It is interesting to note that balenine ( $\beta$ alanyl-His( $\tau \mathrm{Me})$ ) 
has been found in the rat, albeit in small quantities and that this peptide may be responsible for the erratic His( $(\mathrm{Me}$ ) excretion patterns seen in the pig, (Harris \& Milne, 1980).

The increase in His $(\tau \mathrm{Me})$ excretion observed during the later part of the present experiments may have been a reflection of a change in body composition and an increase in the proportion of body mass represented by muscle. Creatinine excretion, however, did not provide conclusive evidence for this since His $(\tau \mathrm{Me})$ excretion increased relative to that of creatinine. It is also possible that the release of His( $\tau \mathrm{Me})$ from muscle is not a random process (see Ward \& Buttery, 1979) and any slight change in His( $\tau \mathrm{Me}$ ) concentration of muscle protein may have quite marked effects upon urinary excretion rates. Alternatively, if the suggestion of Bates et al. (1980) that a significant proportion of His $(\tau \mathrm{Me})$ in the urine originates from tissues other than skeletal muscle is substantiated then the slight change in excretion rates may again not be directly related to changes in muscle breakdown. Further study of this possibility is required. The use of creatinine as an index of muscle mass is also open to criticism especially when studying the effects of nutritional and hormonal stimuli. Thus interpretations of results employing both these techniques must be made with extreme caution (see for example the comments of Tomas et al. 1979).

Table 2. Calculated myofibrillar protein breakdown in rats fed on either a low-protein or an adequate-protein diet

$$
\text { Dietary casein }(\mathrm{g} / \mathrm{kg}) \ldots
$$

Day of experiment ...

Body-wt (g)
Muscle mass $(\mathrm{g})^{*}$
Myofibrillar protein $(\mathrm{g}) \dagger$
Myofibrillar nitrogen $(\mathrm{mg}) \ddagger$
Total muscle His $(\tau \mathrm{Me})$ pool II
( $\mu \mathrm{mol})$
Daily excretion of His $(\tau \mathrm{Me})$
( $\mu$ mol)
Proportion of muscle His $(\tau \mathrm{Me})$
pool excreted daily
Half-life for myofibrillar
protein (d) 8

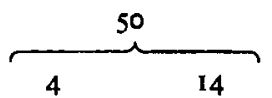

$\begin{array}{cc}102 & 106 \\ 38 & 40 \\ 4.5 & 4 \cdot 8 \\ 720 & 770\end{array}$

$28.9 \quad 30$

$0.52 \quad 0.51$

0.018

$38 \cdot 5$

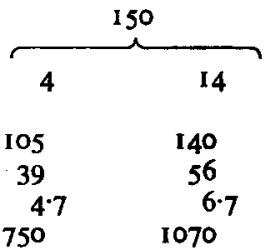

$29 \cdot 6$

0.56

43

$1 \cdot 17$

0.019

0.027

$36 \cdot 5$

* Estimated from the body-weight using the values of Miller (1969).

+ Assuming protein content of muscle $200 \mathrm{mg} / \mathrm{g}$ and $600 \mathrm{mg} / \mathrm{g}$ of protein is myofibrillar protein (Wannemacher, 1975).

$\ddagger$ Calculated assuming protein contains $16 \% \mathrm{~N}$.

$11 \mathrm{His}(\tau \mathrm{Me})$ concentration in muscle $0.76 \mu \mathrm{mol} / \mathrm{g}$.

$\S$ First-order kinetics assumed (Ward \& Buttery. 1978).

The daily excretion of $\mathrm{His}(\tau \mathrm{Me})$ per unit body-weight for rats weighing approximately I00 $\mathrm{g}$ observed in the present study was $5 \mathrm{nmol} / \mathrm{g}$ body-weight which is lower than the I $2 \mathrm{nmol} / \mathrm{g}$ body-weight reported for similar rats by Haverberg et al. (1975). The value obtained in the present study for $150 \mathrm{~g}$ rats $(8 \mathrm{nmol} / \mathrm{g}$ body-weight) was similar to that ( $7 \mathrm{nmol} / \mathrm{g}$ body-weight) obtained by Nishizawa et al. (1977) for $212 \mathrm{~g}$ rats fed on a $200 \mathrm{~g}$ casein $/ \mathrm{kg}$ diet. Haverberg et al. (1975) reported a value of $8 \mathrm{nmol} / \mathrm{g}$ body-weight for rats weighing $278 \mathrm{~g}$. These differences if of any significance are probably consequences of difference in experimental conditions rather than differences in analytical technique. The concentration of His $(\tau \mathrm{Me})$ in muscle determined in this study was similar to that reported by Haverberg et al. (1975).

The fractional rates of myofibrillar breakdown calculated in this study (Table 2) are generally in good agreement with those observed by others, e.g. 0.044 (Millward, 1970) and 
0.029/d (Gudbjarnason et al. 1964). Caution should be observed however, when making such comparisons since the rate of muscle protein breakdown varies considerably with age (see Millward et al. 1975), physiological state (see Trenkle, 1974), muscle type (Earl et al. 1975) and exercise (Goldberg et al. 1975). Swick \& Song (1974) have compiled a table of published half-lives of myofibrillar proteins, which range from 20 to I $45 \mathrm{~d}$.

These values have been obtained using isotopic procedures and for these techniques the shortest experimental half-life is often assumed to approach more closely the true half-life of the protein (Swick \& Song, 1974). Thus the better agreement between the values obtained in this study (Table 2) and the shorter half-lives determined using some isotopic techniques lends some confidence to the potential usefulness of the His $(\tau \mathrm{Me})$ procedure for estimating rates of myofibrillar protein breakdown. Doubt must remain, however, as to the accuracy of such estimates immediately following abrupt changes in diet.

This work was supported by a grant from the Agricultural Research Council. Many helpful discussions with Dr K. N. Boorman are gratefully acknowledged.

\section{REFERENCES}

Armstrong, W. G. (1966). In Techniques in Amino Acid Analysis, p. 73 [D. I. Schmidt, editor]. Geneva: Technicon International Division S.A.

Association of Official Analytical Chemists (1975). Official Methods of Analysis, I2th ed. Washington, DC: Association of Official Analytical Chemists.

Atkin, G. E. \& Ferdinand, W. (1970). Analyt. Biochem. 38, 313.

Bates, P. C., Grimble, G. K. \& Millward, D. J. (1980). Proc. Nutr. Soc. 38, 136 A.

Earl, C. A., Everett, A. W. \& Sparrow, M. P. (1975). Proc. Aust. Physiol. Pharmac. Soc. 6, 108.

Goldberg, A. L., Etlinger, J. D., Goldspink, D. R. \& Jablecki, C. (I975). Med. Sci. Sports 7, 185.

Gudbjarnason, S., Telerman, M., \& Bing, R. (1964). Am.J. Physiol. 206, 294.

Harris, C. I. \& Milne, G. (1978). Proc. Nutr. Soc. 38, i A.

Harris, C. I. \& Milne, G. (1980). Biochem. Soc. Trans. (In the Press).

Haverberg, L. N., Deckelbaum, L., Bilmazes, C., Munro, H. N. \& Young, V. R. (1975). Biochem. J. $152,503$. Miller, S. A. (1969). In Mammalian Protein Metabolism III p. 183 [H. N. Munro, editor]. New York and London: Academic Press.

Millward, D. J. (1970). Clin. Sci. 39, 577.

Millward, D. J., Garlick, P. J., Stewart, R. J. C., Nnanyelugo, D. O. \& Waterlow, J. C. (1975). Biochem. J. 150, 235.

Nishizawa, N., Shimbo, M., Hareyama, S. \& Funabiki, R. R. (1977). Br. J. Nutr. 37, 345.

Owen, J. A., Iggo, B., Scandrett, F. J. \& Stewart, C. P. (1954). Biochem. J. 58, 426.

Payne, P. R. \& Stewart, R. J. C. (1972). Lab. Anim. 6, 135.

Poulter, H. N., Rangeley, W. R. D. \& Lawrie, R. A. (1977). Ann. Nutr. Alim. 3r, 245.

Rao, B. S. N. \& Nagabhushan, U. S. (1973). Life Sci. 12, 205.

Snedecor, G. W. \& Cochran, W. G. (1967). Statistical Methods, 6th ed., Ch. 10. Ames, Iowa: Iowa State University Press.

Swick, R. W. \& Song, H. (1974). J. Anim. Sci.38, I 150.

Tomas, F. M., Munro, H. N. \& Young, V. R. (1979). Biochem. J. 179, I39.

Trenkle, A. (1974). J. Anim. Sci. 38, 1142.

Wannemacher, R. W. (1975). In Total Parenteral Nutrition. Premises and Promises, Ch. 7 [H. Ghandimi, editor]. New York: J. Wiley and Sons.

Ward, L. C. (1976). Muscle protein metabolism, PhD Thesis, University of Nottingham.

Ward, L. C. \& Buttery, P. J. (1978). Life Sci. 23, 1103.

Ward, L. C. \& Buttery, P. J. (1979). Biochim Biophys Acta 587, 415.

Young, V. R., Alexis, S. D., Baliga, B. S., Munro, H. N. \& Muecke, W. (1972). J. Biol. Chem. $247,3592$.

Young, V. R., Haverberg, L. N., Bilmazes, C. \& Munro, H. N. (1973). Metabolism 22, I429. 